\title{
Helpful Hints for Moving or Shifting Collections
}

\section{Anthony J. Amodeo \\ Librarian \\ Illinois Cooperative Conservation Program SIU-Carbondale}

In this era of ebbing financial support for libraries, in which the costs of repair, rebinding and replacement of even ordinary materials continue to climb, it makes perfect sense to take precautions in order to prevent unnecessary damage to collections, especially research collections. It will not be surprising, therefore, to see better handling procedures encouraged in academic libraries, through staff training and patron education, once its costeffectiveness is realized.

The processes involved in moving or shifting a substantial number of library materials make this activity an especially important occasion for staff training and close supervision. If care is not taken, many years worth of wear and tear and accidental damage to materials can be inflicted in a matter of hours. It is with this in mind that the following recommendations are presented.

\section{Marking}

Instead of using pressure-sensitive tags on books for marking range or shelving order, try tall colorcoded or numbered strips of paper that can be inserted either between books or in the first or final book. These slips, always taller than the books themselves, should be removed after the move is complete, since they are probably acidic.

\section{Removal from Shelf}

Staff should be trained to remove books by grasping them at the middle ("waist") rather than tugging at the headcap, which causes damage. Supervisors must be watchful for this, especially as the day wears on and bad habits surface. Adjacent books may be pushed slightly toward the back of the shelf to expose enough of the desired book for grasping.

Books should be grasped securely and in small enough quantity to assure safe handling. Careful handling is cheaper than excessive speed.

All books should be supported in an upright position at all stages of handling or else laid flat. This means that when books are taken from a shelf, the remaining books are not allowed to slouch, sag, or slide. One hand can hold the unsupported book against the remainder of books on the shelf while a second person loads the book truck or cart. An alternative is the use of wrapped housebricks to hold otherwise unsupported books upright: these are easier to manipulate than bookends, and can be slid quickly with one hand. Lacking bricks or bookends, the last three or four books in the row can be stacked flat to provide support. However, if threeperson teams are used for the move (one to remove books, one to place them on the cart, a third to transport the cart), such stacking is usually unnecessary.

An adequate number of stable standing kickstools or other risers should be provided for each team, so that materials on the top shelves will not be yanked off, or the remaining books fall off the shelf for lack of support.

\section{Loading onto Carts}

Bookcarts should be loaded in a prescribed order to prevent both non-sequential transfer into new locations, and any instability of the cart during transit which may cause spills (see illustration). If double rows of books are set on the truck, this becomes of paramount importance. Rare books should only be moved in single rows.

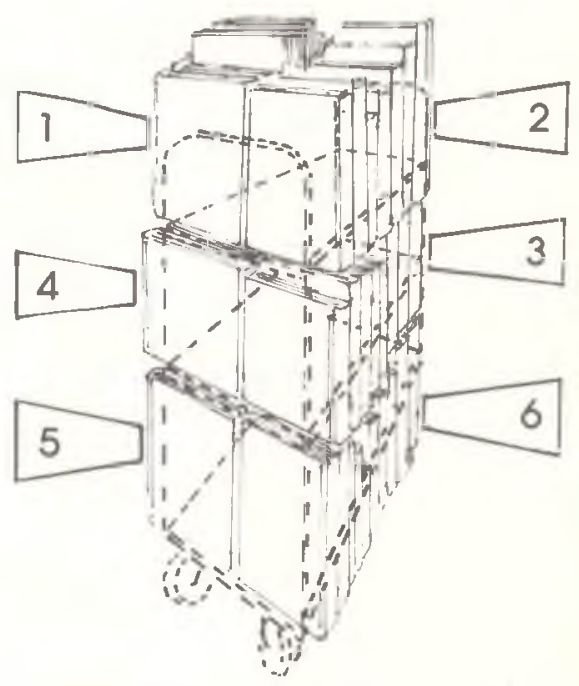

Books should be adequately supported on the carts so that there will be minimum sliding and no leaning during transport. At the same time, books should not be stuffed tightly enough to cause abrasion or crushing. Wrapped bricks can be used to support books during the loading, and bricks or bookends should be used for supporting books during transit if the truck is not filled end-to-end. 
If spillage of material occurs during transit, the cause should be identified and a solution found immediately. Some causes may be: the cart was pushed too fast, especially around corners; large books were loaded in double rather than single rows; the rows were not centered on the cart; books were not adequately supported on the cart, or held too loosely; the type of cart or flooring caused excessive vibration. In the last case, single-row loading should be employed for all books, which should be constantly monitored during transit. If problems persist, inner tubes might be cut into large "rubber bands" about two inches wide and carefully slipped around the cart; the same could be done with lengths of non-abrasive cloth, tied at one end. The surface of the carts might also be padded securely for extra protection

\section{Reshelving}

Materials should be carefully placed in order in their new locations; books will not then need to be slid around to accommodate out-of-sequence material. This is easily accomplished if the cartloading procedure is consistent throughout the move. Location slips can be removed when the shelves have been read.

\section{General Guidelines}

The move should be constantly supervised to avoid the reversion to habit that accompanies fatigue. Adequate break time is important.

Very thick, large, or heavy books are better moved laid flat on the truck. Flat or fragile materials should be protected by a folder or other protective enclosure before the move begins; otherwise, movers should be alerted to their existence and handling. Items in bad repair may have to be bagged, boxed, or tied to avoid loss of parts.

No books should be shelved or carted on their fore-edges; if a large book does not fit upright on the cart or shelf, it should be laid flat or set spine down.

Problems and logiams should be dealt with as they occur, and procedures modified where necessary. Planned alternatives can be useful.

Careless or rough handling of materials should not be tolerated. A worker who cannot modify his or her behavior should be reassigned to less critical work.

After the move has been accomplished, a memorandum or short report should be written to serve as a guide in future moves.

A move can be a useful tool in identifying the maintenance and repair needs of the collection. If adequate staff is available, a system for noting items that need care can be set up and the results subsequently used as resources for appropriate treatment, care. or replacement become available.

Any librarian with a good sense for conservation could compile and add to this set of rules and caveats, just by giving the matter some thought. If the recommendations above seem rather common- sensical-congratulations! You have a good conservation attitude. And much of library conservation has to do with the application of common sense to available information. Similar awareness applied to library routines and tasks, such as reshelving, circulation procedures, and marking, will do much to lower the costs of a library "doing business." This sort of preventative attitude, put into practice, is one of the best and cheapest kinds of conservation.

Editor's note: Any C\&RL News readers who have further tips on handling books during a move and wish to share them, may write to George $M$. Eberhart, ACRL/ALA, 50 E. Huron Street, Chicago, IL 60611 .

\section{HAVE YOU MISSED THESE PUBLICATIONS?}

Take advantage of ACRL's sale and complete your library's holdings by ordering the following tithes at greatly reduced prices. They are available prepaid for the following special prices and with an accompanying mailing label, from ACRL/ALA, 50 E. Huron St., Chicago, IL 60611.

Neturorks and the University Library. (1974). 90 p. Regularly $\$ 3$. Now $\$ 1$. Proceedings of an institute sponsored by the University Libraries Section. Papers by Fred Kilgour, Hugh Atkinson, Brigitte Kenney, and others.

ACRL University Library Statistics, 1978-1979. (1980). 47p. Regularly $\$ 5$. Now $\$ 1$. Statistics from 98 non-ARL university libraries.

Salary Structures of Librarians in Higher Education for the Academic Year 1975- 76. (1976). 33p. Regularly $\$ 2.50$. Now $\$ 1$.

A Directory of Asian and African Librarians in North America. (1978). 33p. Regularly \$5. Now $\$ 2.50$.

Slacic Ethnic Libraries. Museums and Archires in the United States: A Guide and Directory. (1980). 164p. Regularly $\$ 14$ for ACRL members. $\$ 17.50$ for non-members. Now $\$ 6$ for members, $\$ 9$ for non-members.

\section{New from ACRL}

Back to the Books: Bibliographic Instruction and the Theory of Information Sources. (1983.) 76p. $\$ 12$ for ACRL members, $\$ 15$ for non-members. ISBN 0-8389-6587-3. Papers presented at the Bibliographic Instruction Section program at the 1982 ALA annual conference. Edited by Ross Atkinson.

Library Statistics of Colleges and Unitersities: Summary Data. 1979. (1982). 73p. \$10 for ACRL members, $\$ 13$ for non-members. Unpublished data from the National Center for Education Statistics HEGIS survey. 


\section{ACRL/ISI FELLOWSHIPS AWARDED}

Denise D. Bedford, assistant to the director for technical services at the Stanford University $\mathrm{Li}$ braries, has been selected to receive the $1983 \mathrm{Sa}$ muel Lazerow Fellowship for Outstanding Contributions to Acquisitions or Technical Services in an Academic or Research Library. The fellowship is offered jointly by ACRL and the Institute for Scientific Information.

The award was granted for her research proposal on "Technical Processing Costs in Large Academic Research Libraries" and consists of a citation and $\$ 1,000$ to be awarded at ALA Annual Conference in Los Angeles. Bedford's project will test the feasibility of calculating technical processing costs across institutional and organizational boundaries and is scheduled for completion in January, 1984 .

The Samuel Lazerow Fellowship has been established to foster advances in acquisitions or technical services by providing librarians in those fields a fellowship for research, travel, or writing. Proposals are judged on their potential significance, originality, and clarity. The award is named in honor of Samuel Lazerow, a senior vice-president of the Institute for Scientific Information who died in 1981 .

Stanton F. Biddle, associate director for plan- ning and development at the State University of New York at Buffalo Library, has been granted a doctoral dissertation fellowship by ACRL and the Institute for Scientific Information for a proposal entitled "The Planning Function in the Management of University Libraries: Survey, Analysis, Conclusions and Recommendations." Biddle is a doctoral candidate at the School of Library and Information Studies, University of California, Berkeley. The award consists of a citation and $\$ 1,000$ contributed by ISI and will be presented to Biddle at ALA Annual Conference in Los Angeles.

This year's award is the first ACRL Doctoral Dissertation Fellowship to be granted. The purpose of the fellowship is to foster research in academic librarianship by encouraging and assisting doctoral students in the field with their dissertation research.

Recipients of the fellowship must be active doctoral students in the academic librarianship area in a degree-granting institution who have completed all their coursework and had their proposal accepted by the institution. The criteria for judging include the potential significance of the research, methodological validity, originality, clarity, and a convincing timetable.

Applications for next year's awards may be made to Sandy Whiteley, Program Officer, ACRL/ALA, 50 East Huron Street, Chicago, IL 60611. They must be received by December 1, 1983, to be eligible.

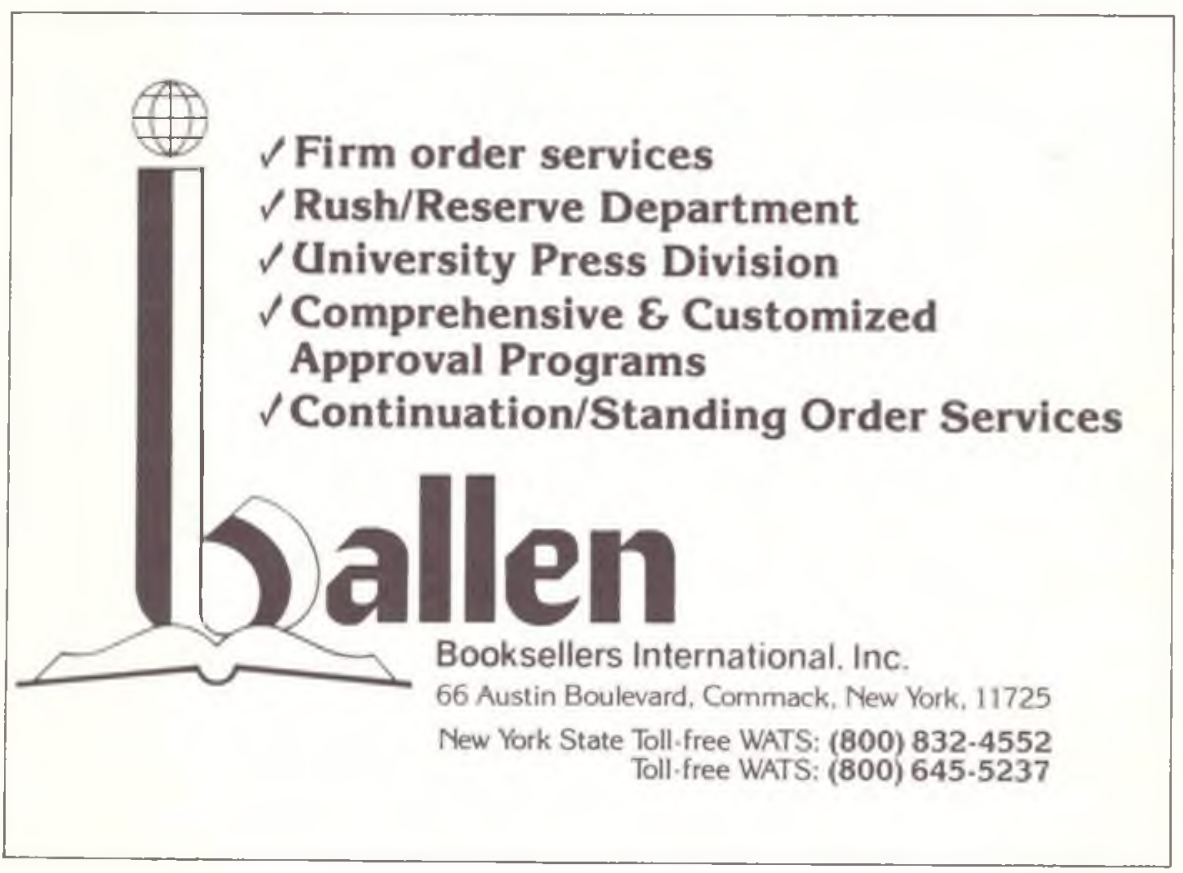

